\title{
ART BEYOND CONTEXT A sociological inquiry into the singularity of cultural creativity
}

\author{
Augusto Santos Silva \\ Faculty of Economics of the University of Porto
}

\begin{abstract}
This article advocates the awareness that art exists also beyond the context. No doubt that art exists within a context. Still, it goes beyond the context. First, each artistic corpus is a structure in itself. Second, it cannot be solely considered from the point of view of context. So, a double dialogue is needed: between social science and art study, and between social science and art itself. We need a dialogue in the Bakhtinian sense, recognizing the plurality of voices, and refusing any authoritative or absolute stance of one of them. If we want to seize the singularity and textuality of the work of art, in all its aspects and consequences, we must allow for this singularity and textuality to penetrate and feed our sociological theory and research, not only as subjects but also as factors of knowledge and interpretation.
\end{abstract}

Keywords: art, sociology, singularity, textuality.

A arte para lá do contexto. Uma abordagem sociológica da singularidade na criação cultural

Resumo O artigo defende que a arte também existe para além do seu contexto. Claro que existe num determinado contexto; não obstante, vai além. De um lado, porque cada obra artística representa por si própria uma certa estrutura, que deve ser analisada como tal. Do outro, ela não pode ser restituída apenas a partir do ponto de vista contextual. Precisamos, assim, de um duplo diálogo: entre as ciências sociais e os estudos artísticos, e entre as ciências sociais e as artes. Um diálogo no sentido de Bakhtine, isto é, que reconhece a pluralidade das vozes em presença e recusa atribuir a qualquer delas uma posição de autoridade absoluta. Se queremos apreender a singularidade e a textualidade de cada obra de arte, em todos os seus aspetos e consequências, temos de deixar que essas características da arte penetrem e alimentem a teoria e a pesquisa sociológica; e que o façam não apenas como objetos de estudo, mas também como fatores de conhecimento e interpretação.

Palavras-chave: arte, sociologia, singularidade, textualidade.

L'art au-delà du contexte. Une enquête sociologique sur la singularité de la création culturelle

Résumé Cet article plaide pour avoir la conscience que l'art se situe aussi au-delà du contexte. C'est évident que l'art existe dans un certain contexte. Pourtant, elle va au-delà de ce contexte. D'abord parce que chaque corpus artistique est par lui-même une structure. Ensuite, parce qu'il n'est pas saisissable du seul point de vue du contexte. Nous avons besoin d'un double dialogue, entre les sciences sociales et les études artistiques et entre les sciences sociales et les arts eux-mêmes. C'est un dialogue à la façon de Bakhtine, qui puisse reconnaitre la pluralité des voix, sans accorder à aucune une position d'autorité absolue. Si nous, les sociologues, voulons relever la singularité et la textualité d'un œuvre artistique, dans tous ces aspects et effets, nous devons permettre à l'œuvre d'art de pénétrer et alimenter notre théorie et nos recherches, et non seulement en tant qu'objet d'étude sinon comme facteur de connaissance et d'interprétation.

Mots-clés: art, sociologie, singularité, textualité.

El arte mas allá del contexto. Una encuesta sociológica sobre la singularidade de la creación cultural

Resumen El artículo sostiene que el arte también existe más allá de su contexto. Por supuesto, existe en un contexto determinado; sin embargo, va más allá. Por un lado, porque cada obra artística representa en sí misma una determinada estructura, que debe ser analizada como tal. Por otro lado, no se puede considerar el arte solo desde el punto de vista contextual. Así, necesitamos un diálogo doble: entre las ciencias sociales y los estudios artísticos, y entre las ciencias sociales y las artes. Un diálogo en el sentido de Bakhtine, es decir, que reconoce la pluralidad de voces y se niega a atribuir a una de ellas una posición de autoridad absoluta. Si queremos aprehender la singularidad y textualidad de cada obra de arte, en todos sus aspectos y consecuencias, debemos 


\section{How to articulate "text" and "context"?}

Take for instance the book La Litérature en Péril. It was published in 2007. Its author, Tzvetan Todorov, a former leading theorist of the formalist school, regrets the overwhelming influence, among critics, of such stances as formalism, nihilism and solipsism. They all ignore the nature of literature as a "discourse on the world" (Todorov, 2007: 31), and therefore disconnect the literary analysis from the social and historical comprehension of the literary works. And now take the book on Kafka by the sociologist Bernard Lahire: Franz Kafka. Eléments pour Une Théorie de la Création Littéraire. He argues he wants to understand "how Kafka writes what he writes the way he writes". Because he refuses "to look at the literary text from a long distance", and instead he aspires "to penetrate into its very flesh" (Lahire, 2010: 9, 14).

So we have a literary theorist whose program is to re-bound literature to history and society; and we have correspondingly a sociologist who proposes a sociological approach not only to the social contexts and conditions of the creative work, but also to its content or substance. They are but examples of a broad group of scientists who contest the dualism between the internal and the external analyses of the works (see Péquignot, 2007). These scientists assume that neither can the works be considered as mere products or echoes of the social structure, nor can they be completely detached from the social environment where they are produced, disseminated and consumed.

It is arguable that the so-called reflex theory - that treated literature and other figurative arts as superstructural effects of some sort of material and social infrastructure - had been already abandoned by qualified researchers a long time ago. Historians and sociologists are now used to focus their attention on the intermediate levels and factors that give complexity to the relations between art and society, and that sustain the structural autonomy of arts: a relative autonomy, of course, still an effective one.

Three lines have been decisive for theoretical and empirical developments. The first one takes into account the supply side of the artistic and cultural sectors. It examines the social, economic and technological conditions of the "production of culture" (see Peterson, 1994), highlights the collective and cooperative nature of the activities taking place in the "art worlds" (Becker, 1982), and/or seeks both the autonomy and interdependency of the "cultural field" in relation to other social fields (Bourdieu, 1992). The second line of research privileges the demand side, focusing on audiences - their composition, tastes, preferences and practices (see, as 
striking examples, Bourdieu, 1979, and Donnat, 2009). And the third line tries to articulate the two sides, identifying the intermediary chains that define the artistic and social value of art, and ensure the distribution and trade of artistic goods. The key role of mediators is highlighted (see Hennion, 1993). Of course, public policies (at national or local level) and the ones implemented by great cultural institutions and non-profit organizations are also powerful intermediaries between supply and demand.

But Todorov and Lahire are calling our attention to something further. Lahire does not want to stop at the front door of the artistic workshop, the door that separates creative "content" from its social environment, as close as this can be. And Todorov does not want to give up the aesthetic, symbolic and technical dimensions of the creative work. They call for a well balanced approach to the inner circle and substance of art.

This is not a unanimous option among sociologists that are far away from the "reflex theory". Some of the most proficient researchers are very cautious concerning a perspective they think does not belong to social sciences. If, says Nathalie Heinich, one wants to grasp sociologically the "singularity regime" of the modern art, one should avoid the axiological and hermeneutic issues, that is to say, the questions of value and meaning, and alternatively focus his or her analysis on a pragmatic approach: what constitutes these works as works of art and how are they socially assessed? Not art itself, but the "uses of art", what art does and what it enables (Heinich, 1999).

Such a pragmatic orientation, well substantiated by Heinich in what regards painting and sculpture, is employed in the field of music by another major art sociologist, Tia DeNora. According to her, the key is to perceive "music-in-action" (DeNora, 2011). Music is not only a product; it is also and mainly a resource for action. In everyday life, people use music to acquire knowledge, express emotions or take control, and the sociologist can analyse the circumstances and outcomes of the uses of music in contexts of social action. The concepts of affordance - denoting the enabling power of music - and event - referring to any kind of action musically informed - are critical to this pragmatic perspective. It makes a large and fruitful use of the interpretation of culture as a "repertory", a toolkit of competences, symbols, habits and lifestyles that people can mobilize, in a variety of ways, in their "strategies of action", in order to make sense of the world and of their existence in the world (Swidler, 1986).

This is a vast and exciting research program for art sociologists. It leads us well beyond the mechanical explanations of literature, music or visual arts as "products" of something else, be it the inspirational lives of individuals or the dynamics of social forces. And it allows undertaking fine case studies that go deep into the complexities of the relationship between creation, production and consumption, providing pertinent descriptions of the social use and assessment of creative work. Still, this program does not answer plentifully to the theoretical question put by scholars like Todorov and Lahire: can we articulate the "text" and the "context" of a work of art, without diluting one of these two dimensions without ignoring the "context" to focus solely on the "text", as the formalists 
criticized by Todorov; and without refusing to penetrate the "flesh" of the "text" from the point of view of the "context", at Lahire's invitation?

\section{Creativity, singularity, textuality}

For sociologists or historians, as well as for cultural economists, the creative nature of the artistic activity and outcome does not constitute, nowadays, a topic for dispute. It means that the value chain necessarily includes some sort of authorship (as an individual contribution that cannot be depicted as an impersonal, standardized and interchangeable position in the production line, but constitutes instead a moral and material attribute and property of the artist); and involves a certain work on, and with, symbols and ideas, which potentially add new perspectives and achievements to the existing stock of texts, images, melodies, performances and so on. Creativity is not only, by definition, a basic ingredient of any cultural good and value (Throsby, 2001:3-4; see also Caves, 2000: 2-10), but must also be envisaged as a dimension transversally relevant to several sectors and activities of the modern economy (and indeed, for some authors, a major characteristic of the so-called knowledge economy).

Therefore, it is not here the origin of the analytical difficulties that social research still faces, when addressing the artistic labour and achievement. Contrarily to the romantic view of the artist as a genius, and the correlative exaggeration of the aesthetic aura and individual charisma, the authorship and the predominance of symbols as work resources for artists can be handled quite satisfactorily with the available tools of economic or sociological theory. The point is elsewhere.

Firstly, we have the issue of singularity. Singularity is, of course, a consequence of authorship - the individual character of creativity and the originality of each creative outcome. The artefact is often designed by a team (as it is the rule in the performing arts or in the film industry); still, the authorial nature of the artistic activity cannot be eluded and it is effectively reckoned, for cultural or economic purposes. As Nathalie Heinich $(1998,2009)$ has shown regarding fine arts, the "regime of singularity" (as opposed to the regime of community of, say, the traditional organisation of arts and crafts) is indeed a key differentiation of modern art. But singularity has an additional meaning: the intrinsic individuality of the work of art, as opposed to the patterned nature of most social activities. If the sociologist's intellectual aim is to grasp the regularities of social action and to identify the patterns (the structures) that organise it, how can a sociological point of view take into account the episodic, individual, specific aspects of each artistic activity and good, that is, its singularity?

The second issue is harder to name. I would dare to name it "textuality", if readers would be kind enough not to interpret such a name literally, as only or predominantly literary (namely, as written texts). The fact is that, on the one hand, and as a symbolic device, a work of art is a semiotic complex, articulating signs in a way that give them a meaning, or an array of possible meanings. Which, in turn, demand a specific process of interpretation by the receivers, according to some 
code(s) and translation rules. On the other hand, as an aesthetic unity, the work of art is a form, a certain composition of words, sounds, colours, movements, and so on, that acquires sense within specific genres of artistic activities and institutions, and in combination with certain patterns of taste and experience, with certain "expectation horizons" of the readers, listeners, or attendants (Jauss, 1994: 49). This core, this "flesh" of a text or a painting or a photograph or a concert cannot be excluded from the analysis, if this one wants to take into account the systemic and specific nature of the creative work.

Of course, a trained sociologist is at ease with the content analysis of, say, a novel or a film, identifying, counting and comparing themes. But more is needed, if one wishes to consider simultaneously content and form, meaning and composition, in figurative arts. And much more is needed, if one also wishes to encompass non-figurative arts or works. The "texture" of the works must be at the very heart of our approach.

None of these issues requires a sort of return to the romantic paradigm of literary or artistic critique. As Pierre Bourdieu (1992) argues, the real foundation of the sociological perspective lies in the prospect of a non-charismatic explanation. In the Durkheimian sense, a piece of art is a "social fact", that must be related to other social facts in order to be accounted for. The symbolic ingredients of a piece of art - its "meaning" - are as "social" as its formal, material or performing aspects, or as the uses people make of it. They are all "dimensions" of social reality. The basic assumption of a sociologist (or historian, or economist) is the situated nature of any work of art (see also Hennion, 1993: 379-380). The tension between "text" and "context" is the crucial ground for any interpretation, and by context we must mean both the environment formed by social structures and events, and the environment formed by other works (the "intertextuality").

One can take advantage of some paradigmatic research on the singularity of arts, perceived from the point of view of history and society. You can explain quite well the singularity of a "genius", if you choose as the subject of your study the social process by which he was constructed, represented and eventually worshipped as a genius: see Nathalie Heinich (1991) on the "glory of van Gogh". You can add an indispensable sociological contribution to the understanding of the astonishing singularity of Mozart, if you call attention to the asymmetry between the pioneering position of Mozart as a free artist and the conventions of the court society in the late eighteenth century. That is the lesson taught by Norbert Elias (1993 [1991]). You seize the irreducible singularity of, say, a novelist if you carefully describe the structure of the literary field to which he belongs; then locate him in that structure; then compare that position with others; then look at the cooperative and/or conflictual relations between the positions; then consider the horizons of possibility opened to the actors in those positions and fields; then grasp the homologies between these structures and dynamics of the cultural field and the ones of other social fields, namely, the economic and political ones; then move from the positions to their occupants and from their occupants to the respective works. That is Bourdieu's method on Flaubert (Bourdieu, 1992). In theoretical terms, You may even be more ambitious and trace the sociology of singularities, showing each 
singularity as a particular case meaning a particular combination of general characteristics, as Bernard Lahire (2004) advocates. Or you can benefit from the economic approach, since you adapt it to the specificities of those markets that value qualities above prices (Karpic, 2007).

The same goes for "textuality". Even Marx and Engels, who are currently credited with the paternity of the "reflex theory", warned their disciples against a mechanistic interpretation of works of art and of what we would now call art worlds (see the essays on Marxism and literature collected in Steiner, 1967). An explanation of that superstructural products and testimonies of economic and social infrastructures, approaching "consciousness" from the point of view of the "conditions of existence", could not circumvent the specificity of the artistic object, that is, could not treat it simply as a perfect mirror or a necessary consequence of social history. The "passage of forms" from one to the other sphere of human activity should be the very core of literary analysis and, in general, of cultural theory (see Hall, 2006 [1980]). Accordingly, Mikhail Bakhtine (1978 [1965]) tried to reconstruct the way Rabelais incorporated central elements of the late mediaeval popular culture, transforming them into literary materials and outcomes. And the program recently designed by Bernard Lahire invites us to take into account the literary metamorphosis: the transposition of the "lived problems" of Franz Kafka into literarily transfigured themes of aesthetic creation (Lahire, 2010). So, you must understand the creative work of the artist (in Lahire's terms, how Kafka writes what he writes) to understand the factors that link it to his social experience - why he writes what he writes.

Many sociologists would therefore agree with the view expressed by the novelist Vladimir Nabokov, considering the masterpiece of another novelist, Marcel Proust. Proust got inspiration and materials for A la Recherche du Temps Perdu from his own experience as a member of the French high society. Not in the manner of a reflection, but in the manner of a refraction: "all he wanted was to refract and, through refraction, to recreate retrospectively a world" (Nabokov, as cited in Ferreira, 2013: 9).

Meanwhile, one can go further. Since the original contribution of the reception theory, it is a well-known fact that the meaning of a work not only depends upon the aesthetic and ideational intent of his or her author, but it depends also on the reception context and process. The author does anticipate the "horizon of reception" of the work he or she is creating, and copes with it according to the genre, style and purpose he or she cultivates. The meaning and destiny of the work is then defined by several, and sometimes very diverse, interpretations, uses and reviews to which it will be submitted. This insight, originally owed to the literary historian Hans Robert Jauss (1994), was subsequently developed by other major cultural research, such as the one Antoine Hennion has been doing in the field of music. The concept of mediation and mediators, key to the latter, is also crucial to fully understand that the "textuality" - the specific substance of a work - heavily depends upon the creative and cultural environment where it takes origin and place. Authors, interpreters, performers, producers, directors, critics, entrepreneurs, audiences, but also material resources and technological devices, currently interplay in 
the very creative process (in ways that, of course, vary significantly according to disciplines, genres and scenes).

\section{A missing element?}

When we employ various analytical perspectives and tools to highlight the singular and autonomous nature of the works of art situated in, and related to, particular and influential social and historical junctures, the outcome can be incredibly proficient. Take the case of François Rabelais, the sixteenth-century French doctor and writer. You can better understand his world view if you first delimit the structure of mental categories to which he could refer to, in his epoch and social group. That is why Lucien Febvre (1942) could demonstrate the impossibility of such a thing as considering Rabelais an "atheist". It would be an anachronism, since this category was not conceivable in the "mentality" to which Rabelais was linked. But, at the same time, the thought and literature of Rabelais were themselves a resultant of the historical changes associated with the European maritime expansion. Certainly not as a direct "product", but in the sense that we can see there an expression (a "transformed" and peculiar expression) of the enlargement of horizons, mental as well as territorial and political, subsequent to that first wave of "globalisation". This has been crucially remarked by the literary historian Eric Auerbach (1977 [1964]: 272-285). And, yet, Rabelais is very close to the late medieval popular tradition of the carnivalesque derision, and he uses it as a major source for his own work. He can be seen, as Mikhail Bakhtine (1978 [1965]) argues, as an innovative user of that tradition as a suitable form for social and intellectual criticism - articulating it with the new kind of problematization that the first steps towards modernity were then affording.

For all these reasons, the work of Rabelais - as the work of any other relevant author, be he or she a novelist, poet, playwright, or painter, sculptor, architect, or musician, film maker and so on - is a unique piece of art and a singular symbolic system. It is a totality. Not because it is "out" of the social world, or could be treated (in a formalistic fashion) as if it was, with no relation to space, time and context, but exactly because it is socially and historically situated, "refracting" the situation in a creative, transforming, original way.

All of this seems, nowadays, quite obvious for everyone who looks into the representational dimension of a piece of art in a manner that simultaneously refuses formalism and sociologism, attempting to overcome the obsolete opposition between internal and external analysis. As mimesis, in the sense used by Auerbach (1977 [1964]), that is, as a representation of reality, each work of art can be understood by exploring the various and complex links that relate it to the cultural and social environment, and the time-space coordinates, in which it is created, circulated and consumed. It is one of the various ways of "telling about society", a representation of society in a specific framework that compares to other representational forms, such as cartography, statistics, ethnography or mathematical models (Becker, 2007). 
This is easier to seize when one considers the narrative elements of a novel; or the interplay of characters in a drama; or the figurative genres in fine arts; or documentary photographs and films; or the meanings ascribed by composers, interpreters, critics or audiences to music; or even the analogies of formal, abstract art with contemporary ways of thinking and acting in society. There is a huge potential in inquiring into such relation between (a) the social world, (b) the art world and (c) the work of art. It did open a path to surpass the restrictive confinement of art sociology to separate analyses on supply and demand, on institutions, markets and audiences, or on public policies.

Revaluating the role of mediators and mediations, this inquiry contributes to the articulation of non-exclusive, complementary dimensions of the same social fact. Assessing the key importance of the art "content" and "form" - let us say, the artistic substance - it allows an approach to literature, visual and performing arts in a manner that does not end in the description of the "systems of belief" (Bourdieu, 1977), the "valuation regimes" (Heinich, 1998), or the "social uses" (DeNora, 2003, Heinich, 1999) of art. And, because it does not exhaust itself in such kind of "surroundings", it gives another meaning and horizon to the pragmatic, empirical analyses on "what makes art possible" and "what art makes possible" (Heinich, 1999: 21).

Indeed, this is the best lens to perceive the vivid and far reaching power of art, not only as a social fact but also as a social factor: a "discourse on the world", as Todorov pertinently says, that expresses but also changes our knowledge, representation, beliefs and expectations about the world; a "repertory" of categories and tools, in Ann Swidler's sense, that subjects can and will use, in "settled" or "unsettled lives" (Swidler, 1986: 277-282); a display of specific materials and events that "afford us" to express knowledge, emotion and control, as DeNora (2003) so persuasively demonstrates in the field of music.

However, I suspect there is something still missing. And this "thing" seems capital, for instance, to distinguish Lahire's attempt to draw the "sociological biography" of Kafka in order to "explain" his literature, from the kind of sophisticated determinism that he criticizes in Pierre Bourdieu. In my opinion, this critique is adequate, but Lahire (2010) ends up presenting an even more sophisticated form of determinism.

It is not easy to identify in a clear, unambiguous, understandable formula what seems to be missing here. But we can go back to Theodor Adorno's view. Not in order to remake his rather highbrow, aristocratic prejudgment against jazz and other forms of allegedly industrial culture. But to take note of something else that remains important. Adorno argued against the reduction of the social dimension of literature and music to its representational features. Poetry, for instance, he said (Adorno, 2003 [1957]: 6-8), is itself social, qualitatively and intrinsically social; and it is more and more social as we come close to the lyrical, individualistic expression - or, in music, to the modern, formal and abstract composition. Adorno viewed art as a necessary ingredient of social life (and I am now referring to Tia DeNora's acute reading of him, see DeNora, 2003: 1-34), namely as art opposes social conformity, through the "negative dialectics" he points out. As the "perennial protest of 
the particular against the general" (Adorno, 2003 [1960]: 113), creativity is a powerful anti-conformist expression: a challenge to social order and social control. This nature of art does not result, according to Adorno, from any other reality besides its very form - its textuality, in the terminology I am using here, or its "textual structure", as he wrote (2003 [1957]: 12), referring to poetry. Any mediation that diverts attention from "text" to "context" is redundant or disturbing (and here I do agree with Latour, 2005: 173-190).

As Antoine Hennion (1993: 129-130) has noted, this is indeed a radical defence of mediation: it denies any functionalist approach to art, and pushes the mediation process into the very core of the work of art. The art is the one that acts as mediator. The logical consequence is the requirement of a sociology that can apprehend each piece of art as a "totality" (Adorno, 2003 [1957]: 7-8), which is a step further in the conception of the singularity of art. Singular and total, each work of music, literature, art, cinema, photography, must be seen and grasped as a "text", a substance in itself. And our knowledge must begin by its "internality".

But how can we construct that kind of knowledge if we renounce axiomatically to the issues of value and meaning, as the most important pragmatic perspectives (such as those of Nathalie Heinich and Tia DeNora) seem to suggest? I say aesthetic value, and not only the illusio Bourdieu speaks about, or the valuation regimes so well described by Heinich. I say semiotic, cultural and artistic meaning, and not only the representations and uses that social actors mobilize in their interactions (and Heinich or DeNora point out).

If we focus on value and meaning, we must consider interpretation. The possibility of explaining the universe of meaning that any work of art inherently constitutes depends crucially on the hermeneutical understanding, as Max Weber taught us. And the possibility of understanding depends fundamentally on the crucial and delicate process of interpretation.

I mean interpretation in two complementary senses: the sense of the anthropologist Clifford Geertz $(1973,1983)$ - that refers to the interrelationship of different cultural codes - and the one of the multifaceted scholar Umberto Eco (1990) that emphasizes the threefold combination of auctor, opus and lector. As any other social fact, art can be conceptualized in terms of play (use, interaction) and of game (relationship, calculus, strategy). But it can only be fully apprehended in terms of "text", the assemblage of signs and ideas in a certain form, sequence and structure. The meaning (in fact, the meanings) of a text, in this general sense, is always the provisional outcome of multiple and intercrossed interpretations, which are proposed by several interveners (such as the authors, performers, readers, teachers, audiences, and the like of them), and that are organised by the categories and codes interpreters use. The basic condition of possibility of interpretation is to recognize the structure of meaning of the interpreted "text" - and the subsequent approach to it, by means of reading, translation and reconstruction. 


\section{Art within and beyond context}

I would then suggest that the "thing" that is perhaps missing in the most interesting research in current sociology of art and culture is the awareness that art "is" also beyond context. I do mean also. The contextualisation of art - that is, the consideration of literature, music or painting from the perspective of its immersion in, and its dialectics with, history and society - is the proper foundation of a sociological approach to this kind of human activity. So, it is the investigation into the characteristics and dynamics of the positions and agents that enrich each cultural field or art world. No doubt that art exists within a context. Still, art goes beyond context, in several senses.

First of all, each artistic system (be it defined by the singular creative work of an artist or group, by a genre or style, by an institutional framework, by a market or a policy, and so on) is a structure in itself. It is an objective set of materials, ideas and symbols that intersects various social and institutional contexts, and partially constitutes a particular, autonomous context. The Simmelian idea of the tension inherent to culture (its "tragedy", in the Greek sense), between the subjective creativity of a singular artist or team and the objective corpus of cultural goods and symbols, may be adopted here (Simmel, 1993 [1911]).

Remember Howard Becker's concept of art world (Becker, 1982). Its capital interest is to point out the network that surrounds a specific work, in which it is conceived, produced, disseminated, and where it acquires meaning and value. The consideration of that network helps to prevent the researcher from the mechanistic view of social determinations influencing directly the artefacts. Now we can go further, and envisage (cumulatively) another mediating network, the one formed by the whole system and process of the specific creative practice and works of an artist. Each stage, form or piece of art belonging to that process and system must be referred, first of all, to its very structure. If, as Becker says (2007: 192), "All cultural objects $[. .$.$] get meaning from context. Even paintings or sculptures, which seem to$ exist in isolation, hanging on the wall of a museum, get their meaning from a context made up of what has been written about them, either in the label hanging beside them or elsewhere, other visual objects, physically present or just present in viewers' awareness, and discussions going on around them or around the subjects the works are about", then the very first context from which a piece of art gets meaning is the structure of the whole work, be it concluded or still in progress, of its author or otherwise maker. This inner circle is irreducible neither to the art world, nor to society at large.

Secondly, to say that art is a "text" beyond "context" (as well as within) implies that it cannot be considered solely from the point of view of context. This one is, of course, very fruitful; but it is not enough. We must understand the text from the context, but also the other way around: as a "discourse on the world" (Todorov again), art is a powerful instrument to understand social context. One knows better the history and the present time of our society if its art is used as a key element of that knowledge - something that produces knowledge, that is knowledge. Something that is not only a "belief" the sociologist can and must deconstruct, but also a 
disclosing or unveiling (as Todorov suggests, 2007: 69-78), or a disclosure of the successive layers that make up our reality (as in Calvino, 1988). Or - to quote now a sociologist - something that emphasizes "the particularity of each representation" (Hennion, 1993: 217). Thus, art can be seen as "an instrument of research" (Péquignot, 2007: 287), or even as an "epistemological partner to sociology" (Majastre, cited by Péquignot, 2007: 286).

If this is correct, a double dialogue is needed. And that is my third and final remark. Dialogue means that two different entities communicate reciprocally. I do not advocate any kind of merger. The sociological and, generally speaking, social scientific agenda and method are quite distinct from the ones that disciplines akin to aesthetics, literary studies, musicology or art criticism put in practice. And yes, as social scientists, context is our point of departure. But, if we do wish to renounce any attempt, even a sophisticated one, to circumscribe art to an effect of society - the society at large, or specific institutions, markets, professions, organisations, ideologies, and so on - we do need to dialogue with those disciplines and colleagues: we do need to build and then cross over bridges that can bring together our different ways of interpreting and our different interpretations. I mean dialogue in the Bakhtinian sense: "dialogical" is the voice that recognizes the plurality of voices, refusing any authoritative or absolute stance of a single one over the others. Multivocality is the necessary condition for dialogue (Bakhtin[e], 1981 [1975]; see also Becker, 2007: 204-222).

So it goes for the first dialogue, between social science and art study. But there is another, more challenging one: the interaction between social science and art itself. Not only because they both "tell about society", "representing/interpreting" society (see Becker, 2007), but also because they both transform and create social realities (ideas, images, discourses, patterns of behaviour, expectations, prospects, events, agency). If we want to seize the singularity and textuality of the creative work, in all its aspects and consequences, we must allow this singularity and textuality to penetrate and feed our theory and research, not only as subjects but also as factors of knowledge and interpretation.

Let me take, as an empirical case, our study on Portuguese punk (see, for instance, Silva and Guerra, 2015). The underground music scenes are full of discourses and practices that propose a worldview and a stance towards society. Within these scenes, many people question and challenge what they think to be moral and cultural hegemonies. They want to do so from the point of view of "below" - the subterranean, marginal side of social order. They want to turn upside down what that order takes for granted, in terms of verbal and body language, self-presentation, communication skills and channels, political common sense, ideological values, patterns of family, labour and civic discipline, autocratic or democratic rules, and everyday life.

They intend to accomplish this by making music in a certain way. Making music, because musical composition, performance, sharing and dissemination enable their self-fulfillment, belonging to in-groups and in proximity to their peers, opposing out-groups, expressing emotions, feelings and desire, publicly and tribally representing themselves. Musical events and resources do empower them, as 
Tia DeNora demonstrated for other genres and occasions. Making music in a certain way is making it in the "underground", on the margins, out or in the periphery of both the social system and the music industry, challenging their rules and constraints, and making music according to the principles of the "do it yourself" culture. And the music and social world thus redesigned is cosmopolitan, urban and youthful. A lot of energy to express what is more than the loudness of the sound or the apparent ugliness of the lyrics, bodies or accessories.

Through all these mediations, these chains and networks, communities and divisions, some musical scenes are built and rebuilt, and a public presence is achieved, in the media, the streets and the garages, bars, clubs and small concert halls. What social knowledge does this form? What social representations are produced? What moral assessments are conveyed? What patterns of action and interaction are favored? How does this (heterogeneous, unstable, ambiguous, slippery) "text" express, influence and overcome the social, urban, youthful context in which it is generated or hosted?

Perhaps a Bakhtinian dialogue would be useful. Perhaps a dialectical tension, in analysis and public discourse, between sociologists and other scholars and critics, and between all those experts and the musicians, producers and audiences of the underground music, could help us to find appropriate, pertinent and sharable answers to all these questions. And they could also help us to treat adequately and to cope with the irreducible singularity and specificity of the artefacts and performances at stake. For the latter - the artistic singularity and specificity - is a necessary condition of the former - the cognitive as well as moral dimensions of the artistic discourse.

We could go even further. Even the Aristotelian idea that there is a "truth" of fiction that surpasses the "truth" of history (an idea appreciated by Marx, see Steiner, 2012 [2011]: 112) could prove helpful to the social scientist, if well understood. This truth can derive from the particular approach inherent to the literary inquiry. A great novelist and scholar, W. G. Sebald (2014 [2003]: 183), formulated it as a work of "restitution", going beyond "the mere report of facts and beyond knowledge". I prefer the terms of a theologian, Elmar Salmann, as cited by cardinal Tolentino de Mendonça (2018: 49-50), currently in charge of the Vatican Library and Archive, and a renowned poet and theologian: literature is a "tool of sapience", because of its metaphorical power, because of the non-conceptual nature of the knowledge it provides, and because of its precision, attentive as it is to singularity and complexity. Anyway, the accuracy of the artistic re-creation of reality (not only representation, but actual re-creation) can and must be a companion to our own sociological account. To say it in those old, still pertinent, words, the "truth" of art can enrich the "truth" of social analysis.

And what if Alain's sentence - "Toute pensée commence par un poème" - could also apply to science? If the work of thinking, of creating, even of inventing, that is so crucial for the scientific method, implies a proximity to language and arts that can empower the interpretation of human agency, which is at the very heart of social research? If Steiner's wonderful inquiry into the association between thought and poetry (Steiner, 2012 [2011]) could be extended to the association of, at least, social science and literature? 
This topic would require an entire new essay. So, let me just refer, to conclude, to two of the greatest Portuguese writers. The seventeenth century preacher António Vieira once said, in praise of another writer, that the latter knew "how to say the common with singularity, the similar without repetition, the already known and ordinary with novelty, and showing things as the light does: anyone as it is, and the whole of them as a chandelier". This is art, "the particularity of each representation" (I am citing again Hennion), in literature as in cinema, in music as in the fine arts. And the twentieth century poet Fernando Pessoa (who, in fact, partially quoted Vieira, see Pessoa, 2010: 223) once said that "literature, as any form of art, is a confession that life is not enough" (Pessoa, 2005: 504). This would be a good reason for a sociological move from (social) life - the very fundament of sociology - to art, whenever sociology wants not only to research on social contexts, uses and representations of art, but also wishes to add value to the understanding and interpretation of art - to the holistic apprehension of the incredible individuality and strength of every art form and work.

\section{References}

Adorno, Theodor W. (2003 [1957]), Poesia Lírica e Sociedade [Rede uber Lyrik und Gesellschaft], transl., Coimbra, Angelus Novus.

Adorno, Theodor W. (2003 [1960]), “Cultura e administração" [Kultur und Verwaltung], transl. in Sobre a Indústria da Cultura, Coimbra, Angelus Novus, pp. 107-132.

Auerbach, Erich (1977 [1964]), Mimésis. La Représentation de la Réalité dans la Littérature Occidentale [Mimesis. Dargestellte Wirdlichkeit in der Abendlandischen Literatur], transl., Paris, Gallimard.

Bakhtine, Mikhail (1978 [1965]), L'CEuvre de François Rabelais et la Culture Populaire au Moyen Age et sous la Renaissance [Tvorcestva Fransua Rable i narodnaja Kutlt'ura stednevokv'ja i Renessansa], trans., Paris, Gallimard.

Bakhtin[e], Mikhail (1981 [1975]), The Dialogical Imagination. Four Essays [Voprosy literatury I estetiki], trans., Austin, University of Texas Press.

Becker, Howard S. (1982), Art Worlds, Berkeley, University of California Press.

Becker, Howard S. (2007), Telling about Society, Chicago, The University of Chicago Press.

Bourdieu, Pierre (1977), "La production de la croyance. Contribution à une économie des biens symboliques", Actes de la Recherche en Sciences Sociales, 13, pp. 3-43.

Bourdieu, Pierre (1979), La Distinction. Critique Sociale du Jugement de Gô̂t, Paris, Minuit.

Bourdieu, Pierre (1992), Les Règles de l'Art. Genèse et Structure du Champ Littéraire, Paris, Seuil.

Calvino, Italo (1988), Lezioni Americane. Sei Proposte per il Prossimo Milennio, Milan, Garzanti.

Caves, Richard (2000), Creative Industries. Contracts between Art and Commerce, Cambridge, MA, Harvard University Press.

DeNora, Tia (2003), After Adorno. Rethinking Music Sociology, Cambridge, Cambridge University Press.

DeNora, Tia (2011), Music-in-Action. Selected Essays in Sonic Ecology, Surrey, Ashgate. 
Donnat, Olivier (2009), Les Pratiques Culturelles des Français à l'Age Numérique. Enquête 2008, Paris, Editions La Découverte.

Eco, Umberto (1990), I Limiti dell'Interpretazione, Milan, Bompiani.

Elias, Norbert (1993 [1991]), Mozart, Sociologia de Um Génio [Mozart, zur Soziologie eines Genies], transl., Porto, Asa.

Febvre, Lucien (1942), Le Problème de l'Incroyance au XVIe Siècle. La Religion de Rabelais, Paris, Albin Michel.

Ferreira, António Mega (2013), O Essencial sobre Marcel Proust, Lisbon, Imprensa Nacional.

Geertz, Clifford (1973), The Interpretation of Cultures, New York, Basic Books.

Geertz, Clifford (1983), Local Knowledge. Further Essays in Interpretive Anthropology, New York, Basic Books.

Hall, Stuart (2006 [1980]), "Encoding/decoding”, in Stuart Hall et al. (Eds.), Culture, Media, Language. Working Papers in Cultural Studies, 1972-79, reed., Oxon, Routledge, pp. 128-138.

Heinich, Nathalie (1991), La Gloire de Van Gogh. Essai sur l'Anthropologie de l'Admiration, Paris, Minuit.

Heinich, Nathalie (1998), Ce que l'Art Fait à la Sociologie, Paris, Minuit.

Heinich, Nathalie (1999), Pour en Finir avec la Querelle de l'Art Contemporain, Paris, L'Échoppe.

Heinich, Nathalie (2009), Faire Voir: L'Art à l'Epreuve de Ses Médiations, Les Impressions Nouvelles.

Hennion, Antoine (1993), La Passion Musicale. Une Sociologie de la Médiation, Paris, Métailié.

Jauss, Hans Robert (1994), Pour Une Esthétique de la Réception, transl., reed., Paris, Gallimard.

Karpic, Lucien (2007), L'Economie des Singularités, Paris, Gallimard.

Lahire, Bernard (2004), La Culture des Individus. Dissonances Culturelles et Distinction de Soi, Paris, Editions La Découverte.

Lahire, Bernard (2010), Franz Kafka. Eléments pour Une Théorie de la Création Littéraire, Paris, Editions La Découverte.

Latour, Bruno (2005), Reassembling the Social. An Introduction to Actor-Network-Theory, Oxford, Oxford University Press.

Mendonça, José Tolentino de (2018), Elogio da Sede, Lisbon, Quetzal.

Péquignot, Bruno (2007), La Question des CEuvres en Sociologie des Arts et de la Culture, Paris, L'Harmattan.

Pessoa, Fernando (2005), Obras em Prosa, ed. Cleonice Berardinelli, reed., Rio de Janeiro, Nova Aguilar.

Pessoa, Fernando (2010), Livro do Desassossego, ed. Jerónimo Pizarro, vol. I, Lisbon, Imprensa Nacional Casa da Moeda.

Peterson, Richard A. (1994), “Culture studies through the production perspective: progress and prospects", in Diane Crane (Ed.), The Sociology of Culture. Emerging Theoretical Perspectives, Cambridge, MA, Blackwell, pp. 163-189.

Silva, Augusto Santos, and Paula Guerra (2015), As Palavras do Punk. Uma Viagem fora dos Trilhos pelo Portugal Contemporâneo, Lisbon, Alêtheia. 
Simmel, Georg (1993 [1911]), "Le concept et la tragédie de la culture" [Der Begriff und die Tragödie der Kultur], trans. in La Tragédie de la Culture et Autres Essais, 2. ${ }^{\text {nd }}$ ed., Paris, Rivages, pp. 179-217.

Sebald, W. G. (2014 [2003]), Campo Santo, transl., Lisbon, Quetzal.

Steiner, George (1967), Language and Silence. Essays on Language, Literature, and the Inhuman, New York, Atheneum.

Steiner, George (2012 [2011]), A Poesia do Pensamento. Do Helenismo a Celan [The Poetry of Thought. From Helenism to Celan], transl., Lisboa, Relógio d'Água.

Swidler, Ann (1986), "Culture in action: symbols and strategies", American Sociological Review, 51 (2), pp. 273-286.

Throsby, David (2001), Economics and Culture, Cambridge, Cambridge University Press. Todorov, Tzvetan (2007), La Littérature en Péril, [Paris], Flammarion.

Augusto Santos Silva. Full professor of the Faculty of Economics of the University of Porto, and researcher at the Institute of Sociology of the same University. His main interests are related to sociology of culture and arts, and to political theory. E-mail: asilva@fep.up.pt

Receção: 20 de abril de 2020 Aprovação: 08 de maio de 2020 
